\title{
Enhanced Electrical Properties of Crystalline Silicon Solar Cells via Nano-Composite Polyvinyl-Alcohol/Titanium Dioxide
}

\author{
Ali Kadhim Naser ${ }^{*}$, Dhafer Manea H. Al-Shamkhee ${ }^{2}$, Qahtan Adnan Abed ${ }^{2}$ \\ ${ }^{1}$ Engineering Technical College, Najaf, Al-Furat Al-Awsat Technical University, Najaf 31001, Iraq \\ ${ }^{2}$ Technical Institute, Al-Rumaitha, Al - Furat Al- Awsat Technical University, Najaf 31001, Iraq
}

Corresponding Author Email: alikadhim558@gmail.com

https://doi.org/10.18280/ijdne.160510

Received: 18 June 2021

Accepted: 13 August 2021

\section{Keywords:}

$\mathrm{TiO}_{2} / \mathrm{PVA}$ nanocomposite, solar cell, thermal regulation thin film, $U V$ - mask, anti-reflection coating

\begin{abstract}
Reflection loss and solar cell temperature both have a significant impact on solar cell efficiency and, consequently, on power generation. Herein, the aim is to investigate into the impact of Nanocomposite Titanium Dioxide $\left(\mathrm{TiO}_{2}\right)$ /Polyvinyl Alcohol (PVA) on polycrystalline silicon solar cells. The solvent casting method is employed to prepare nanocomposite $\mathrm{TiO}_{2} / \mathrm{PVA}$ for deposition on the front side of the solar cell. The Tauc plot is used to investigate the influence of $\mathrm{TiO}_{2}$ nanoparticle concentration $(10-20 \mathrm{~nm})$ on the energy bandgap of a nanocomposite. To test the optical properties of the solar cell after depositing the Nanocomposite coating film and to confirm the suspension of $\mathrm{TiO}_{2}$ in PVA and construct a Nanocomposite, an ultraviolet-visible spectrometer and a Fourier transform infrared spectrometer are provided. The results show that increasing the $\mathrm{TiO}_{2}$ in the $\mathrm{TiO}_{2} / \mathrm{PVA}$ Nanocomposite increases the energy bandgap. The Ultraviolet-Visible spectrometer observes that the Nanocomposite films absorb the Ultraviolet wavelength and transmittance at the visible wavelength. Finally, it found the lowest reflection obtained was $3.9 \%$ for $0.2 \mathrm{wt} \% \mathrm{TiO}_{2}$ in $\mathrm{TiO}_{2} / \mathrm{PVA}$ nanocomposite and the enhancement of the solar cell efficiency was $(+2.3 \%)$.
\end{abstract}

\section{INTRODUCTION}

The world's electrification and consumption are reliant on energy sources. Traditional energy sources are non-renewable and rapidly depleting. The infinite available in nature renewable sources, such as solar and wind. Even if renewable energy extraction is more expensive, maintenance costs are low, and power can still be mined without any demand [1]. Solar power is an environmentally friendly and cost-effective energy source as compared to other options. The Sun generates energy by converting $650,000,000$ tons of hydrogen into helium through a thermonuclear reaction. This process generates heat and electromagnetic radiation, spreading across the atmosphere. Just 57 percent of these rays penetrate the earth's surface, containing $1.6 * 1018$ units of energy from the sun [2].

There are numerous viable renewable energy resources in development, with photovoltaics emerging as the most promising as a potentially clean and sustainable energy technology to substitute for fossil fuels. The expansion of the photovoltaic (PV) market necessitates the advancement of high-performance and low-cost silicon solar cell processing technologies focused on optimizing the "cost-to-efficiency" ratio for larger-scale mass production. Multi-crystalline silicon (mc-Si) solar cells have recently dominated the market, accounting for half of all PV modules produced worldwide. When combined with high conversion efficiency and dependability, several factors limit the performance of these photovoltaic systems: solar radiation reflection and rising surface temperature of the solar cell, both of which result in solar cell conversion efficiency losses. So, fabrication of an indispensable antireflection coating and controlling the solar cell's temperature control the wavelength absorbed in the silicon solar cell. And as known, the excess photon's energy to eject an electron is released as heat on the surface solar cells [3].

Due to their various uses in batteries, air and water purification, surface coating, solar cells, and packaged food, the polymer matrix in nanocomposites has been studied extensively [4]. Polymers serve as the matrix and nanoparticles serve as the filler in polymer matrix nanocomposites. Nanocomposites vary from traditional composite materials in that the reinforcing process has a high surface-to-volume ratio and the reinforcing particles are well dispersed in the matrix [4]. Filler materials in conventional composite materials are in the micrometer range, while nanocomposite materials have filler materials that are on the nanoscale, i.e. 1-100 nm. The integration of inorganic nanofillers into organic polymers has been the subject of recent research $[5,6]$. Nanoparticles of Titanium dioxide, TiP, and TiW, for example, have been doped into polymeric materials such as PANI, Polyamide, and Polyvinyl alcohol to create nanocomposite materials $[7,8]$.

Yahia et al. [9] stated that $\mathrm{TiO}_{2} / \mathrm{PVA}$ nanocomposites can be employed in various areas of laser power attenuation, and UV-blocking to save human skin. Kawata et al. [10] uncovered that the film with Polyaniline (PAni)/ $\mathrm{TiO}_{2}$ nanocomposites has poor adhesion to the FTO glass. Experimentally, Zaini et al. [11] studied the behaviour of a mono-crystalline solar PV panel and reported that the electrical parameters change with a variation in temperature. He et al. [12] demonstrated that combining a novel zinc coating with a good appearance and a 
nano-metric watery paint is a promising strategy to make the painting material safe, economical, and environmentally friendly. Nosrati and Olad [13] created unique nonocomposite coatings and demonstrated that modified polyacrylic coatings have a lower glass transition temperature than unmodified polyacrylic coatings.

Zaini et al. [14] managed to combine nano-sized titanium dioxide with various organic binders and use them as a coating to study their effects on the performance of solar cells. Nosrati et al. [15] prepared several photocatalytic coatings and claimed that the coatings containing $2 \%$ and $3 \%$ $\mathrm{TiO}_{2} /$ polypyrrole nanocomposite were the best coating formulations. In same respect, Nosrati et al. [16] employed spectroscopy analysis and revealed that a modified coating efficiently decolorized a dye contaminant.

PVA is water soluble and ethanol soluble, unlike most other organic solvents. Vinyl acetate monomer is the main raw material used in PVA. It can be deposited as a thin layer on the surface as well as a thick layer of the desired shape and size via the solution casting process, mentioned by Kumar et al. [17, 18]. Because of their low electric charge and low thermal conductivity, all polymers are insulating. Some authors have reviewed the conductivity of polyvinyl alcohol film $[19,20]$. Anatase, brookite, and rutile are the three phases of $\mathrm{TiO}_{2}$ present in nature. The crystal structure of anatase and rutile is tetragonal, while that of brookite is orthorhombic. The phase and particle size of titanium dioxide affect the properties of nanocomposites [21].

In current research, we are investigating nanocomposite, polyvinyl alcohol-titanium dioxide and its effect on improving the efficiency of the crystalline silicon solar cell. $\mathrm{TiO}_{2} / \mathrm{PVA}$ nanocomposite films are created using the dip-coating process. The characteristics of nanocomposites $\mathrm{TiO}_{2} / \mathrm{PVA}$ are done with UV-V spectroscopy and a solar module analyzer to check the solar cell parameters. Thermal studies and the influence of solar cell surface temperature on output power are conducted using K-type thermocouples with a computerized data logger. The formation of a Ti-O-O bond, which helps in the suspension of nanosize titanium dioxide in polyvinyl-alcohol, is verified by FTIR results.

\section{EXPERIMENTAL SETUP DESIGN}

Figure $1 / \mathrm{A} \& \mathrm{~B}$ depicts the general process for preparing thin films coating nanocomposite $\mathrm{PVA} / \mathrm{TiO}_{2}$ while a rigged solar cell tester to calculate solar cell parameters that are applied in this work is shown in Figure 2.

The experimental steps depicted in Figure 2 are detailed in the subsections that follow as described.

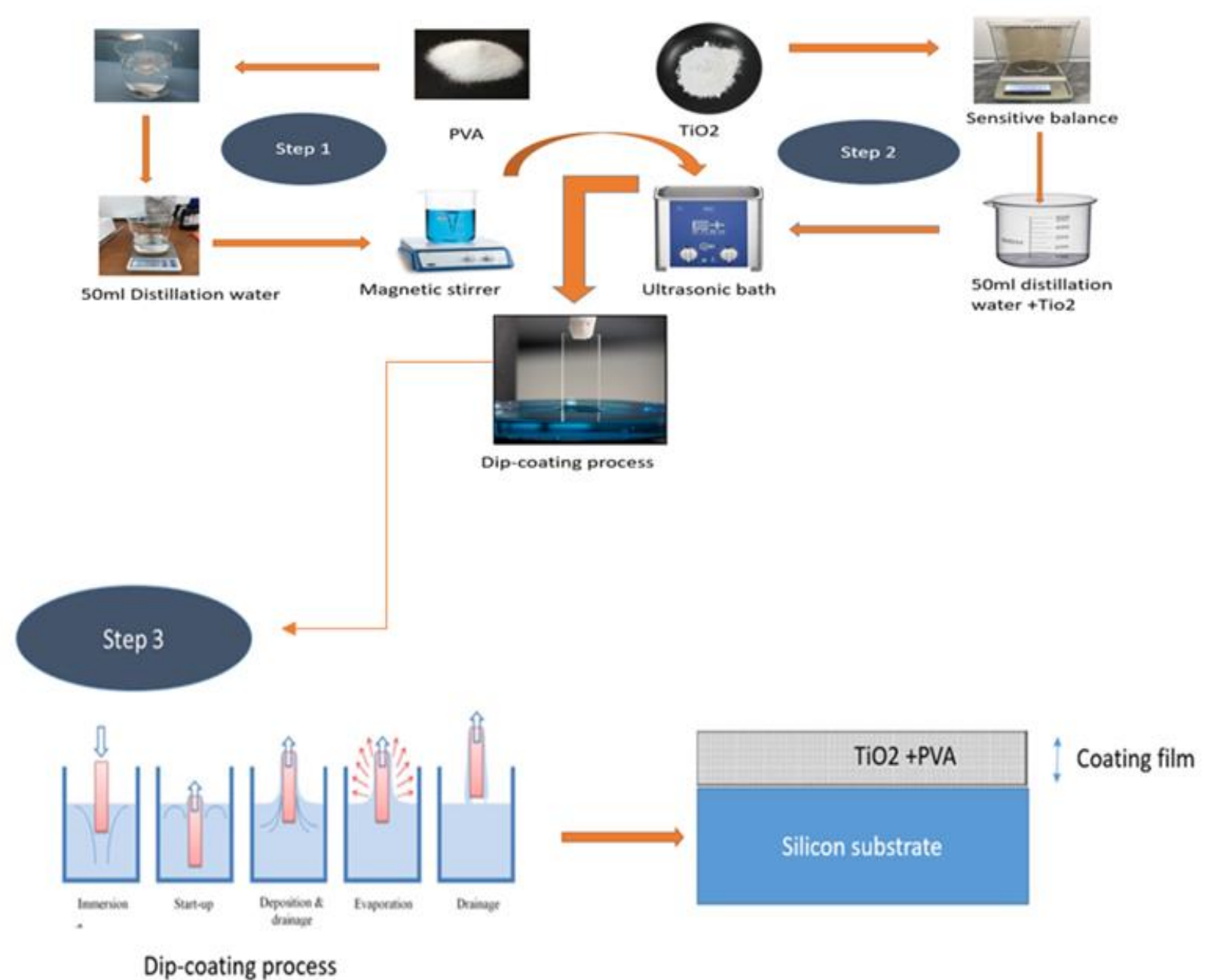




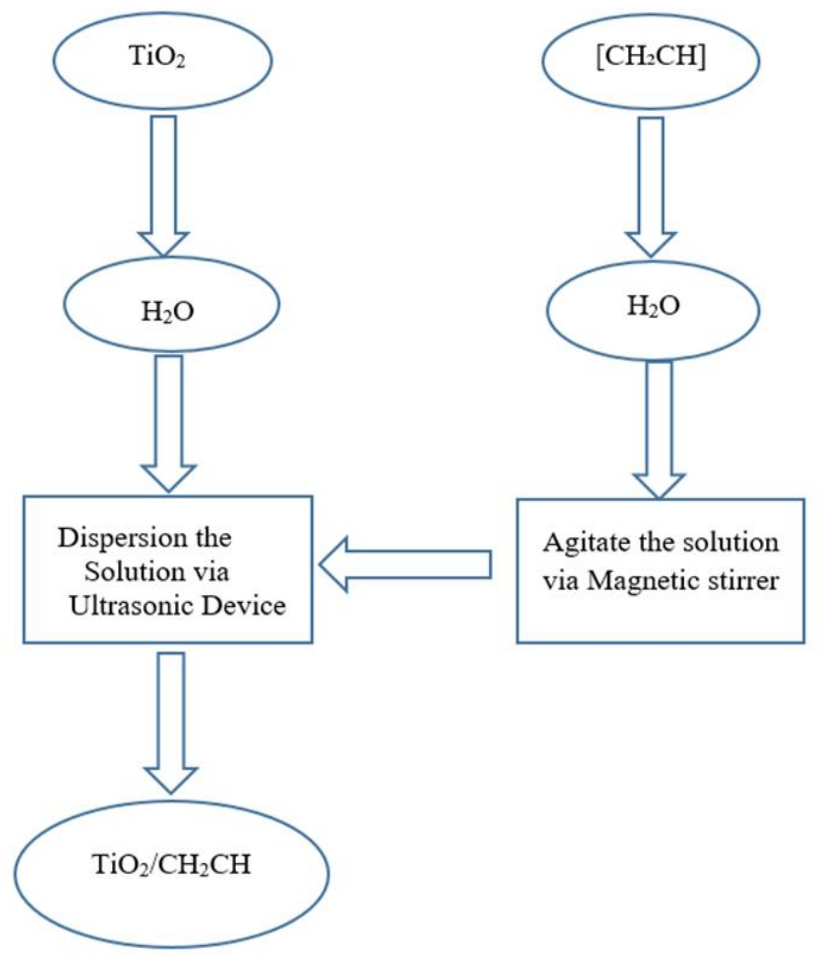

(B)

Figure 1. (A). Schematic diagram of $\mathrm{PVA}+\mathrm{TiO}_{2}$ coating film preparation; (B). Flow chart Nanocomposite preparing

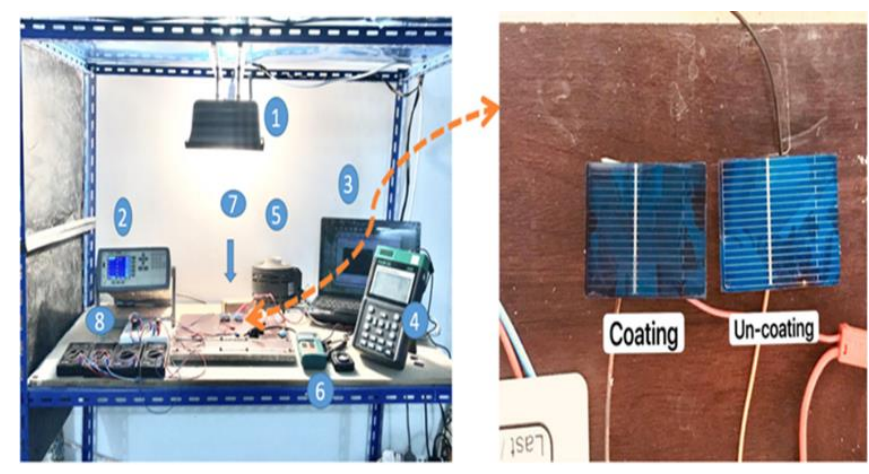

Figure 2. Experimental setup design (Rig solar cell test) (1) Lamp (2) data logger (3) PC- laptop (4) Solar cell module analyzer (5) Variac light intensity (6) Pyrometer/solar power meter device (7) Mc-si solar cells coating and un-coating (8) Wider stander/resistor

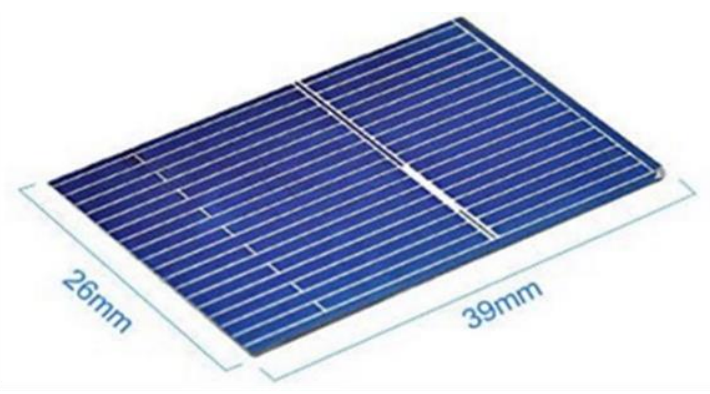

Figure 3. Polycrystalline silicon solar cell

\subsection{Geometry description}

A Multi-crystalline Silicon solar cell with a dimension of $26 \times 39 \mathrm{~mm}^{2}$ was used in this study as pictured in Figure 3.

\subsection{Washing the samples}

The sample ( $\mathrm{Si}$ solar cell) was cleaned very well as per the following protocol. The substrates were placed in a beaker containing water and detergent, then placed in an ultrasonic bath for 15 minutes, during which they were washed several times with water. The process was repeated with Acetone instead of detergent.

Finally, the substrates were left to dry at room temperature. Thus, the samples are completely free of dirt and contaminants and ready to work.

\subsection{Prepare polyvinyl alcohol (PVA)}

PVA solution was made by dissolving 1 gram of PVA in 50 milliliters of distilled water and stirring it at room temperature at 300 RPM until it became transparent. This solution was filtered with $45 \mu \mathrm{m}$ paper and allowed the solution to sit until it was no longer visible in the foam. To prevent the formation of bacteria, the mixture is tightly sealed. To prepare all of the samples, the technique was performed four times.

\subsection{Prepare the polyvinyl alcohol/titanium dioxide nanocomposites}

$\mathrm{TiO}_{2}$ nanoparticle solutions were made by dissolving 0.1 gram, 0.05 gram, 0.025 gram, and 0.00125 gram of $\mathrm{TiO}_{2}$ NPs in 50 milliliters of distilled water. As a result, titanium dioxide solutions containing $0.2,0.1,0.05$, and $0.0025 \mathrm{wt}$ percent were prepared and left it 4 hours under sonicated process. The solution of PVA was made at the same time by dissolving 1 gram of PVA in 50 milliliters of distilled water and stirring at room temperature. With continuous sonication, solutions of $\mathrm{TiO}_{2}$ were applied to PVA solution in the form of drops. After this, solution has been thoroughly mixed. To prepare all of the nanocomposite film concentrations, the same process was repeated.

There are many main objectives for doping the Polyvinyl Alcohol in Titanium Dioxide solution. To begin with, the PVA has the absorption property in the wavelength spectrum in the ultraviolet region (200-400). In addition, it prevents the Titanium dioxide nanoparticles from being an agglomeration because the $\mathrm{TiO}_{2}$ particles are entrapped and encapsulated by the Polyvinyl Alcohol chains. By increasing the solution viscosity (incrementing the PVA concentration), the motion of the encapsulation particles slows down. In conclusion, the existing PVA in $\mathrm{TiO}_{2}$ solution and creating Nanocomposite $\mathrm{TiO}_{2} / \mathrm{PVA}$ aimed at forming a film on the solar cell because it has excellent film-forming ability.

In other words, it could explain the preparation process through specific steps. Through the $\mathrm{TiO}_{2}$ dispersion process. The $50 \mathrm{ml}$ of the PVA solution was dropped into the $\mathrm{TiO}_{2}$ solution at a rate of $12.5 \mathrm{ml}$ every 30 minutes after the first two hours of the total dispersion period (four hours).

$\mathrm{UV}-\mathrm{V}$ is spectroscopy, a solar module analyzer to examine the optical properties of synthesized nanocomposites and solar cell parameters. Thermo-couples K-types with data loggers were used to study the thermal insulation capability of the film.

It can describe the absorption unit as follows:

$$
A=\varepsilon b C A
$$

where,

Absorbance [absorption unit (A.U)]: $\mathcal{E}$ Molar absorptivity $(\mathrm{L} /($ mole. $\mathrm{cm}))$ b: path length $(\mathrm{cm}), \mathrm{C}$ : concentration $($ mole $/ \mathrm{L})$. 


\subsection{Measurement of thin-film thickness}

The thickness of prepared thin-film can be measured by micrometer (Micro-printer) Figure 4. pictured that device. It is also easy to measure thickness by means, as the device is calibrated before Initiation to measurement. The thickness of the layer is measured before and after the coating process and by knowing the difference. To get a more precise thickness, multiple readings from various locations on the base's surface are taken, and the sum of those readings is used to calculate the average thin-film thickness $(0.62 \mu \mathrm{m})$.
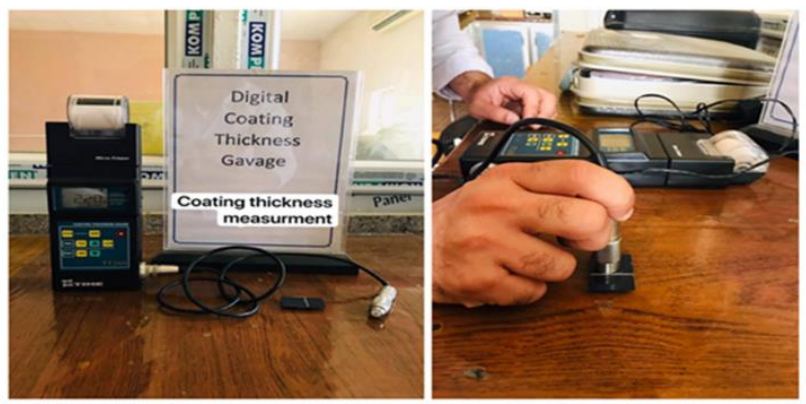

Figure 4. Thin-film thickness measurement (micro-printer)

\section{RESULTS AND DISCUSSIONS}

\subsection{Ultraviolet-visible absorption analysis}

To test the UV-Vis absorption properties of prepared nanocomposites, the UV-Vis spectra of native PVA and $\mathrm{TiO}_{2} / \mathrm{PVA}$ nanocomposites ranged from 200 to $700 \mathrm{~nm}$ and were presented as shown in Figure 5. Accordingly, the pure PVA has a $275 \mathrm{~nm}$ absorption wavelength. 338, 370, 390, and $360 \mathrm{~nm}$ are the absorption wavelengths of nanocomposite $\mathrm{TiO}_{2} / \mathrm{PVA}$ specimens at $0.2,0.1,0.05$, and $0.0025 \mathrm{wt} \%$, respectively. These absorption peaks can be traced back to $\pi$ $\pi^{*}$ transitions. On the other hand, PVA only showed an absorbance of (330 to 360) $\mathrm{nm}$ in the UV zone. The bands of absorption were broadened in nanocomposites, and the intensity depended on the weight percentage of titanium dioxide nanoparticles doped. Besides, the maximum broadening was investigated when $\mathrm{TiO}_{2}$ nanoparticles were doped with 0.05 weight percent. Finally, the results demonstrate that the 0.2 weight percent of $\mathrm{TiO}_{2}$ doped into the polymer has the highest intensity. Therefore, nanocomposite PVA/ $\mathrm{TiO}_{2}$ films can be employed as ultraviolet filters due to their selective absorbance capabilities.

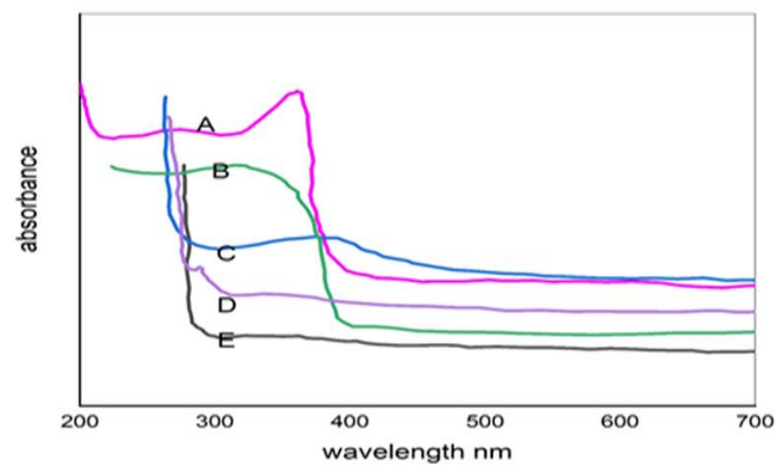

Figure 5. UV-Vis spectrameter . (E) native PVA (A) 0.2 wt $\% \mathrm{TiO}_{2} / \mathrm{PVA}$ nanocomposite (D) $0.1 \mathrm{wt} \% \mathrm{TiO}_{2}$ (C) 0.05 wt $\% \mathrm{TiO}_{2}$ (B) $0.025 \mathrm{wt} \% \mathrm{TiO}_{2}$

\subsection{Energy gap calculations}

Tauc's relationship was used to measure the bandgap of the polyvinyl alcohol film and the prepared nanocomposite (titanium dioxide-polyvinyl alcohol) films. Tauc plot is used to determine the optical bandgap, or Tauc bandgap, of either disordered or amorphous semiconductors. Typically, a Tauc plot shows the quantity $\mathrm{h} v$ (the photon energy) on the abscissa and the quantity $(\alpha h v) 1 / 2$ on the ordinate, where $\alpha$ is the absorption coefficient of the material.

As shown in Figure 6, on the y-axis ( $\alpha \mathrm{hv})$ and on the $\mathrm{x}$-axis (hv), the graph was plotted. Calculating the straight-line portion of the graph extrapolated curves provided the bandgap values. The bandgap of pure PVA was $4.1 \mathrm{eV}$, but loading $\mathrm{TiO}_{2}$ nanoparticles increased the bandgap of nanocomposites. Also, 0.2, 0.1, 0.05, and $0.0025 \mathrm{wt}$ percent doping had bandgaps of $5.27 \mathrm{eV}, 4.6 \mathrm{eV}, 4.44 \mathrm{eV}$, and $4.25 \mathrm{eV}$, respectively. It seems that the bandgap steadily increases as the weight percentage of $\mathrm{TiO}_{2}$ nanoparticles in nanocomposites increases. Therefore, these TiO2/PVA films with a high bandgap may be used as antireflection coatings in photovoltaic panels.

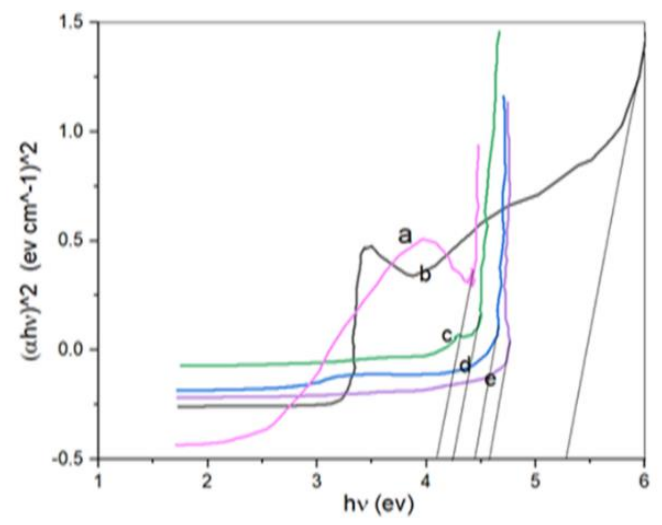

Figure 6. Tauc plot; (a) native PVA (b) 0.2 wt- $\mathrm{TiO}_{2}$ (c) $0.0025 w t-\mathrm{TiO}_{2}$ (d) $0.05 w t-\mathrm{TiO}_{2}$ (e) $0.1 w t-\mathrm{TiO}_{2}$

\subsection{Fourier transforms infrared spectroscopy analysis}

Fourier transforms infrared spectroscopy (FTIR) is a useful tool for observing interactions between polymer constituents by varying vibration modes and band positions [22].

Figure 7 illustrates the Fourier transforms infrared spectroscopy of $\mathrm{TiO}_{2} / \mathrm{PVA}$ and nanocomposite. FTIR over the rigion 400-4000 $\mathrm{cm}^{-1}$ wavelength was presented. PVA has distinct bands at $2850-3000 \mathrm{~cm}^{-1}, 3600-3650 \mathrm{~cm}^{-1}, 3200-3570$ $\mathrm{cm}^{-1}$, and $1000-1200 \mathrm{~cm}^{-1}$, which correspond to $\mathrm{C}-\mathrm{H}$ alkyl stretching bands, hydroxyl groups, hydrogen-bonded bands, and C-O stretching bands, respectively [23]. Crystallization is defined by the stretching band of PVA at $1140 \mathrm{~cm}^{-1}$ [8]. In $\mathrm{TiO}_{2}$ doped PVA nanocomposites, the Ti-O stretching band, is found at $700 \mathrm{~cm}^{-1}$. At $515 \mathrm{~nm}$, a new band corresponding to the Ti-O-O bond has been discovered, which helps to suspend titanium dioxide NPs in polyvinyl alcohol [22]. PVA and nanocomposites $\mathrm{TiO}_{2} / \mathrm{PVA}$ have bands that are identical to those previously used.

\subsection{Nanocomposite $\mathrm{TiO}_{2} / \mathrm{PVA}$ as an antireflection coating thin-film}

Polycrystalline silicon solar cells suffer from high reflection, resulting in a loss of almost $30 \%$ of the incident energy. This 
reduces the power output and, as a result, the performance of the solar cell. This study uses a Nanocomposite coating of titanium dioxide $\left(\mathrm{TiO}_{2}\right)$ with different concentrations $(0.1$ gram, 0.05 gram, 0.025gram, 0.00125gram) and a polymer type polyvinyl alcohol (PVA) with a concentration of (1-gram) on the front surface of the solar cell. The UV-Vis reflectance spectrum investigated the Nanocomposite reflection as shown in Figure 8. The bare polycrystalline silicon solar cell had a reflection of $35 \%$, which was reduced to $10.25 \%, 8.3 \%, 6.1 \%$, $3.9 \%$ for $0.2 \mathrm{wt} \%, 0.1 \mathrm{wt} \%, 0.05 \mathrm{wt} \%, 0.0025 \%$, respectively.

\subsection{The effect of $\mathrm{TiO}_{2} / \mathrm{PVA}$ nanocomposite on solar cell temperature}

Figure 9 illustrates the solar cell surface's temperature after one hour of $1,000 \mathrm{~W} / \mathrm{m}^{2}$ irradiation. Initially, all of the cells' surface temperatures are the same, which is around $25^{\circ} \mathrm{C}$, and then Both solar cells' temperatures increased over time, at various steady-state temperatures. The temperature steadily stabilized by the end of the 1-hour test. The temperature of the uncoated solar cell is higher (WOC $=83.70 \mathrm{C}$ ), Other cells with different concentrations have temperatures of $\left(78.4^{\circ} \mathrm{C}, 76.91^{\circ} \mathrm{C}, 75.4^{\circ} \mathrm{C}\right.$, and $74^{\circ} \mathrm{C}$ with coatings of 0.2 , $0.0025,0.1,0.05 \mathrm{wt} \%$ respectively, which are marginally lower than the uncoated cell. The findings prompt discussions about how UV radiation can play a role in the process that leads to these outcomes. UV radiation is well known for causing solar devices to degrade [24, 25]. In the solar cell industry, the majority of previous studies show that titanium dioxide NPs can effectively filter ultraviolet radiation in many cases [26]. In contrast to previous research, this study emphasizes the use of polyvinyl alcohol as a matrix material to synthesize nanocomposites because of its film-forming capability, and it plays a key role in determining the performance of PVA/ $\mathrm{TiO}_{2}$ at solar panel temperature. According to the findings, the $0.05 \mathrm{wt}$ coating method provides the best UV radiation filtration among the prepared concentrations and has the lower solar cell surface temperature.

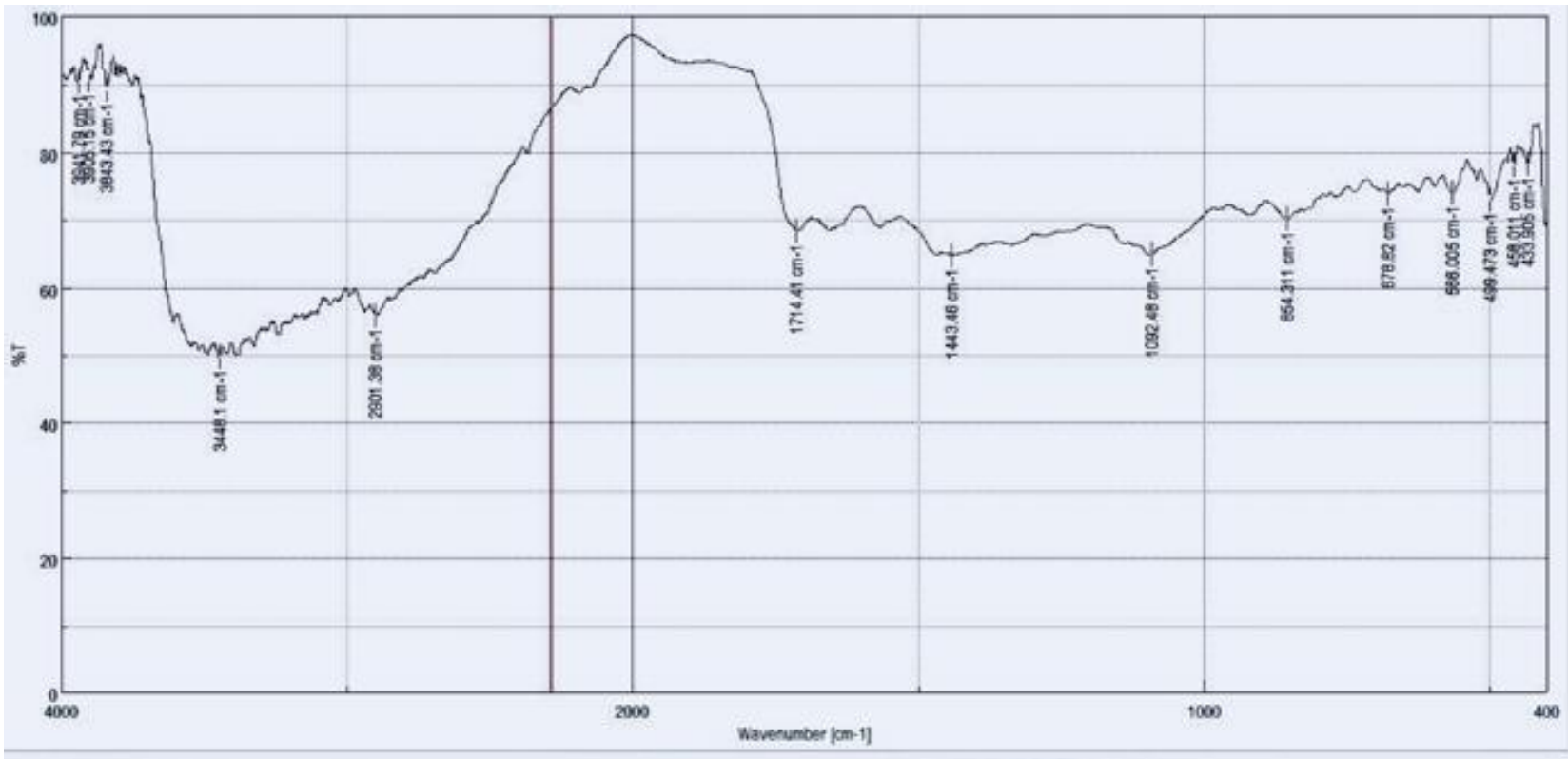

(1) อม-แmanze

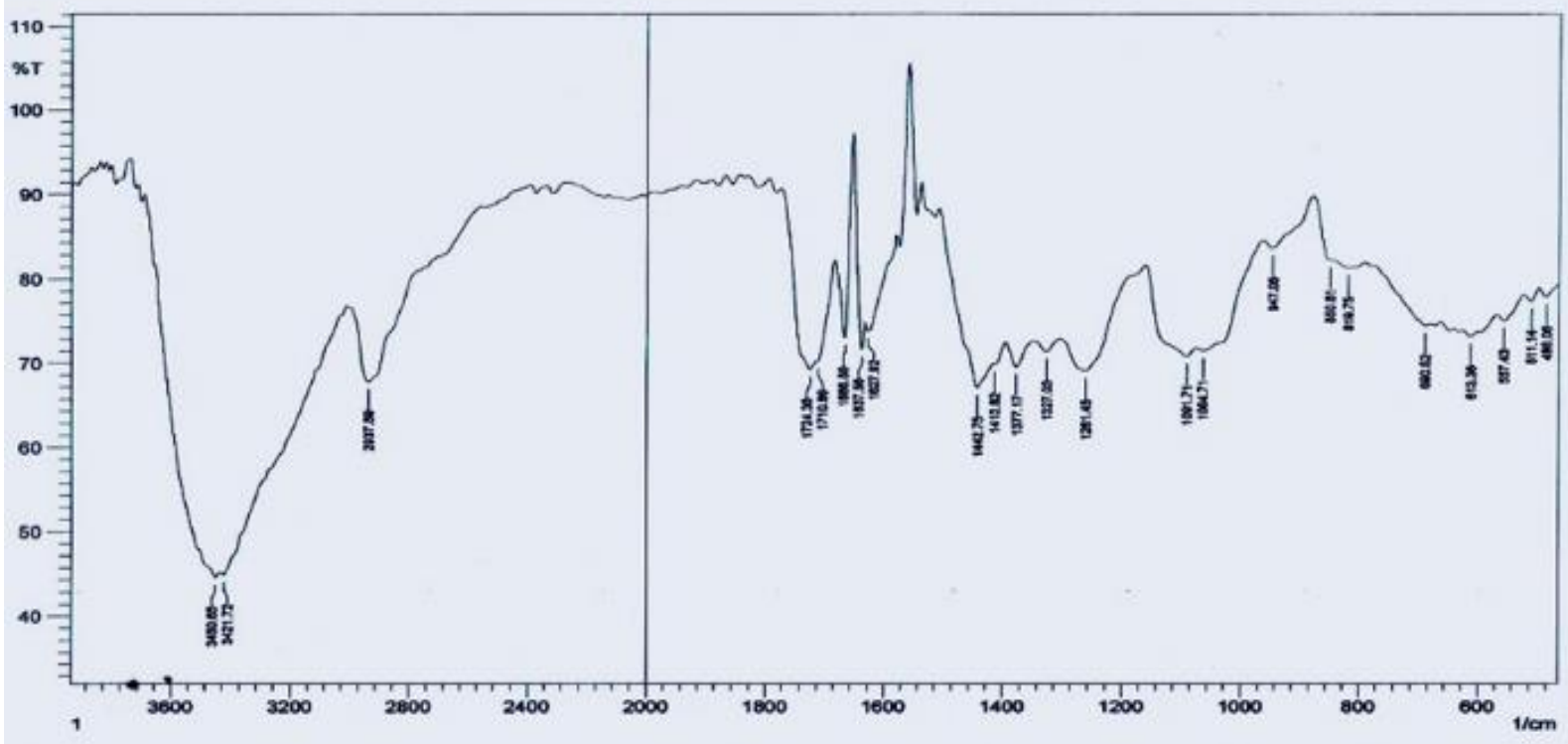

Figure 7. Fourier transforms infrared spectroscopy: Native (PVA) and Nanocomposite $\left(\mathrm{TiO}_{2}-\mathrm{PVA}\right)$ 


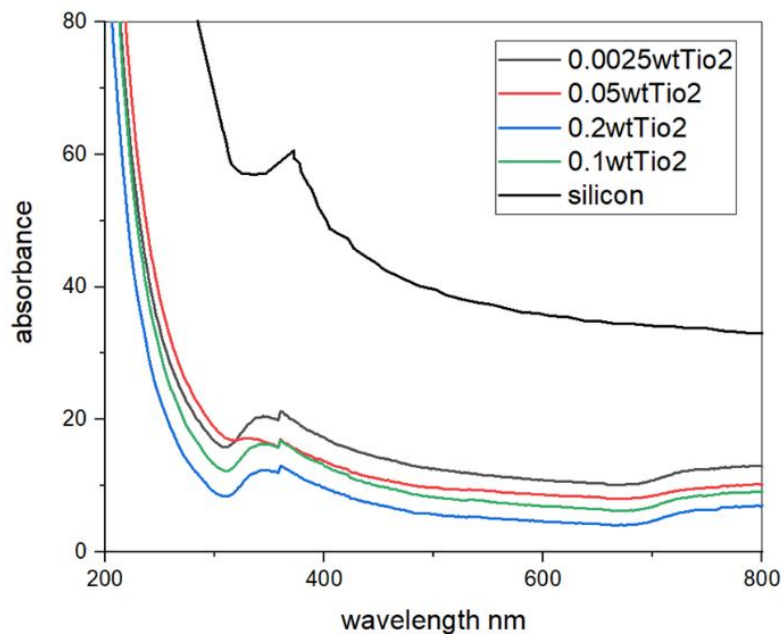

Figure 8. Anti-reflection measurements for different concentrations of $\mathrm{TiO}_{2} / \mathrm{PVA}$ Nanocomposite

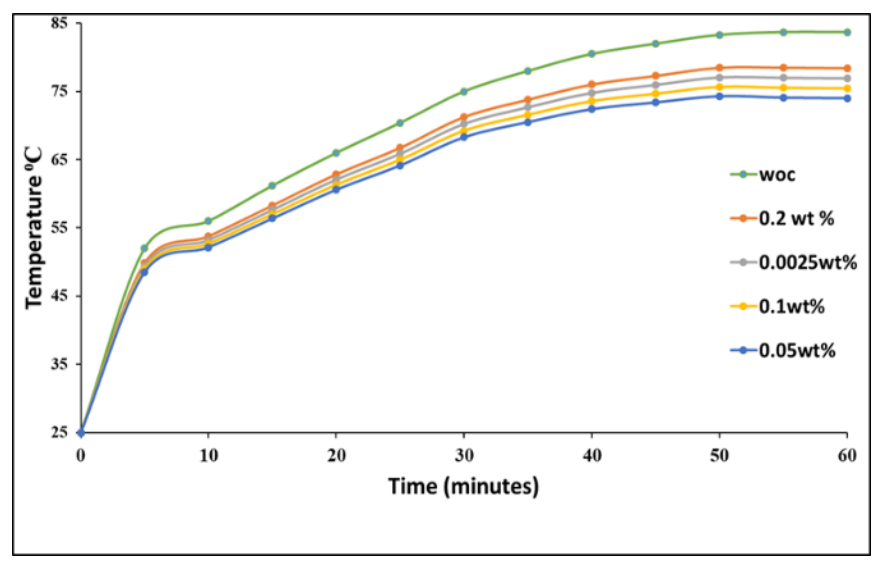

Figure 9. Temperature Vs. time nanocomposite $\mathrm{PVA} / \mathrm{TiO}_{2}$ coating silicon solar cell

\subsection{I-V \&P-V curves characteristics}

Figures 10-11 \& Table 1 show the current-voltage, powervoltage characteristics of a polycrystalline silicon solar cell. Temperature variations and reflection loss have an impact on all of these characteristics. Solar module analyzer type PRAVO-200 was utilized to consider the effect of Nanocomposite $\mathrm{TiO}_{2} / \mathrm{PVA}$ with different concentrations $(0.1$ $\mathrm{g}, 0.05 \mathrm{~g}, 0.025 \mathrm{~g}$, and $0.00125 \mathrm{~g})$ with $(1 \mathrm{~g})$ of Polyvinyl alcohol. The test was indoor with controlling room temperature at $\left(25^{\circ} \mathrm{C}\right)$ and fixed radiant flux $\left(1000 \mathrm{w} / \mathrm{m}^{2}\right)$ with a normal light to the solar cells.

The test for each model took an hour, at zero time (antireflection effect only, there was no temperature effect). All of the solar cells (with different concentrations) have a positive effect compared to a solar cell without Nanocomposite and as noted in the figure, higher enhancement was for the lower reflection loss $3.9 \%$ for $(0.2 \mathrm{wt} \% \mathrm{~g})$ (Pmax: $0.168 \mathrm{~W}$, VOC: $0.535 \mathrm{~V}$, ISC: $0.366 \mathrm{~A}, \eta: 16.5 \%$ ) and the minimum enhancement for higher reflection loss $(10.25 \%)$ at $(0.0025$ wt\%) (Pmax: 0.1494 W, VOC: $0.51 \mathrm{~V}$, ISC: 0.3507 A, $\eta: 14.9 \%)$.

In comparison to without coating (Pmax: $0.144 \mathrm{~W}$, VOC: $0.5 \mathrm{~V}$, ISC: $0.34 \mathrm{~A}, \eta: 14.2 \%$ ), the relationship between the Nanocomposite concentrations and the power enhancement was linearly. After one hour (total test time), the effect of the temperature deterioration due to the Eq. (1). The results show that minimum temperature effect on the solar cell power output was for minimum temperature $74^{\circ} \mathrm{C}$ for $(0.05 \mathrm{wt} \%)$ which $(23.7 \%)$ after one- hour test time, while without coating at the same condition test record $26.5 \%$ of the power output loss due to temperature effect at $83.7^{\circ} \mathrm{C}$. Accordingly, that varying in temperature effect was significantly observed in the figure, that varying was due to the effect of concentrations on the Ultraviolate ray absorption.

$$
\eta=\eta_{r}\left(1-\beta\left(T_{C}-T_{r}\right)\right)
$$

Table 1. Data extracted from solar module analyzer (PROVA- 200A) for coating and without coating (WOC) Polycrystalline silicon solar cell

\begin{tabular}{ccccccc}
\hline samples & VOC $_{\text {OV }}$ & ISC (A) & P MAX $_{\text {M }}$ ) & Temperature after 1-h & Reflection\% & $\boldsymbol{\eta}(\boldsymbol{\%})$ \\
\hline WOC & 0.5 & 0.34 & 0.144 & $83.7^{\circ} \mathrm{C}$ & $35 \%$ & $14.2 \%$ \\
$0.2 \mathrm{wt} \%$ & 0.535 & 0.366 & 0.168 & $78.4^{\circ} \mathrm{C}$ & $3.9 \%$ & $16.5 \%$ \\
$0.1 \mathrm{wt} \%$ & 0.53 & 0.36 & 0.1632 & $75.4^{\circ} \mathrm{C}$ & $6.1 \%$ & $16.1 \%$ \\
$0.05 \mathrm{wt} \%$ & 0.52 & 0.355 & 0.1573 & $74^{\circ} \mathrm{C}$ & $8.3 \%$ & $15.52 \%$ \\
$0.0025 \mathrm{wt}$ & 0.51 & 0.3507 & 0.1494 & $76.9^{\circ} \mathrm{C}$ & $10.25 \%$ & $14.7 \%$ \\
\hline
\end{tabular}

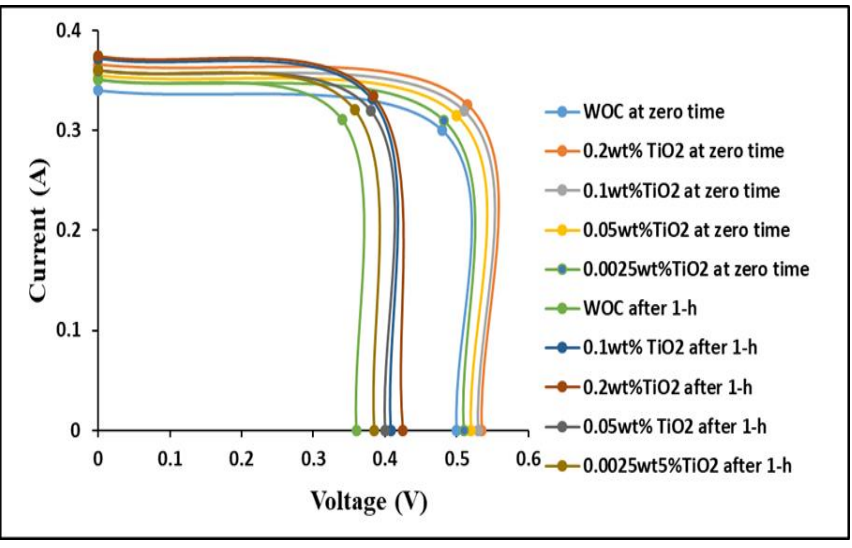

Figure 10. Current Vs. Voltage Nano-composite PVA/ $\mathrm{TiO}_{2}$ coating crystalline Si solar cell

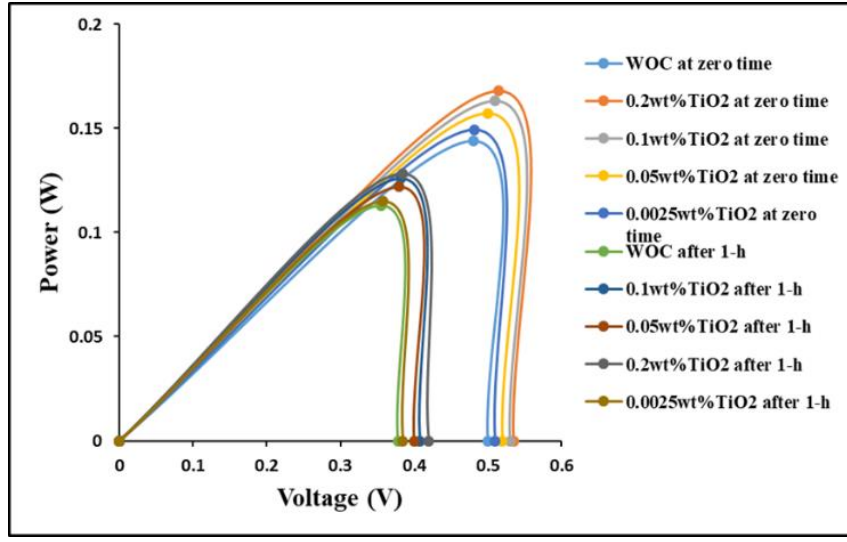

Figure 11. Power Vs. Voltage to coating, un-coating mc-si solar cells 


\section{CONCLUSION}

Four different concentrations of $\mathrm{TiO}_{2}(0.2 \mathrm{wt} \%, 0.1 \mathrm{wt} \%$, $0.05 \mathrm{wt} \%$, and $0.0025 \mathrm{wt} \%$ ) were doped into PVA and created a Nanocomposite $\mathrm{TiO}_{2} / \mathrm{PVA}$. A casting technique was employed to deposit the Nanocomposite on the front side of the polycrystalline silicon solar cell. The Ti-O-O bond enables us to suspend $\mathrm{TiO}_{2}$ nanoparticles in PVA and was confirmed using FTIR. UV-Vis spectrometer shown the ability of the Nano-coating to absorbed the ultraviolet wavelength at different broadened depend on the $\mathrm{TiO}_{2}$ wt $\%$ in $\mathrm{TiO}_{2} / \mathrm{PVA}$. The maximum broadening was investigated When $\mathrm{TiO}_{2}$ nanoparticles doped with 0.05 weight percent. The findings uncover that the energy bandgap increased as the $\mathrm{TiO}_{2}$ increased. Also, $5.27 \mathrm{eV}$ was the maximum energy bandgap with $0.2 \mathrm{wt} \%$ of $\mathrm{TiO}_{2}$. Besides, the surface solar cell temperature $\left(9.7^{\circ} \mathrm{C}\right)$ was the maximum temperature variation when compared to without coating solar cell. Finally, the solar module analyzer PROVA-200A investigated the maximum efficiency enchantment of $(+2.3 \%)$, where the bare solar cell was $14.2 \%$ and the maximum enhancing solar cell with nanocomposite was $16.5 \%$.

\section{REFERENCES}

[1] Garche, J., Dyer, C.K., Moseley, P.T., Ogumi, Z., Rand, D.A., Scrosati, B. (Eds.). (2013). Encyclopedia of Electrochemical Power Sources. Newnes.

[2] Wu, J. (2009). When group-III nitrides go infrared: New properties and perspectives. Journal of Applied Physics, 106(1): 5. https://doi.org/10.1063/1.3155798

[3] Sivasankar, G., Sundarapandy, T., Kottaisamy, M. (2018). Development of nano-composite coating for silicon solar cell efficiency improvement. Materials Today: Proceedings, 5(1): 1759-1765. https://doi.org/10.1016/j.matpr.2017.11.273

[4] Singh, R., Kulkarni, S.G., Channe, S.S. (2013). Thermal and mechanical properties of nano-titanium dioxidedoped polyvinyl alcohol. Polymer Bulletin, 70(4): 12511264. https://doi.org/10.1007/s00289-012-0846-3

[5] Mallakpour, S., Barati, A. (2011). Efficient preparation of hybrid nanocomposite coatings based on poly (vinyl alcohol) and silane coupling agent modified $\mathrm{TiO}_{2}$ nanoparticles. Progress in Organic Coatings, 71(4): 391398. https://doi.org/10.1016/j.porgcoat.2011.04.010

[6] Radoičić, M.B., Šaponjić, Z.V., Marinović-Cincović, M.T., Ahrenkiel, S.P., Bibić, N.M., Nedeljković, J.M. (2012). The influence of shaped $\mathrm{TiO}_{2}$ nanofillers on thermal properties of polyvinyl alcohol. Journal of the Serbian Chemical Society, 77(5): 699-714. http://dx.doi.org/10.2298/JSC110331161R

[7] Khan, A.A., Baig, U., Khalid, M. (2011). Ammonia vapor sensing properties of polyaniline-titanium (IV) phosphate cation exchange nanocomposite. Journal of Hazardous Materials, 186(2-3): 2037-2042. https://doi.org/10.1016/j.jhazmat.2010.12.107

[8] Ma, X., Wang, M., Li, G., Chen, H., Bai, R. (2006). Preparation of polyaniline- $\mathrm{TiO}_{2}$ composite film with in situ polymerization approach and its gas-sensitivity at room temperature. Materials Chemistry and Physics, 98(2-3):

241-247.

http://dx.doi.org/10.1016/j.matchemphys.2005.09.027

[9] Yahia, I.S., Mohammed, M.I., Nawar, A.M. (2019).
Multifunction applications of $\mathrm{TiO}_{2} /$ poly (vinyl alcohol) nanocomposites for laser attenuation applications. Physica B: Condensed Matter, 556: 48-60. http://dx.doi.org/10.1016/j.physb.2018.12.031

[10] Kawata, K., Gan, S.N., Ang, D.T.C., Sambasevam, K.P., Phang, S.W., Kuramoto, N. (2013). Preparation of polyaniline/ $/ \mathrm{TiO}_{2}$ nanocomposite film with good adhesion behavior for dye-sensitized solar cell application. Polymer Composites, 34(11): 1884-1891. https://doi.org/10.1002/pc.22595

[11] Zaini, N.H., Ab Kadir, M.Z., Izadi, M., Ahmad, N.I., Radzi, M.A.M., Azis, N. (2015). The effect of temperature on a mono-crystalline solar PV panel. In 2015 IEEE Conference on Energy Conversion (CENCON), pp. 249-253. https://doi.org/10.1109/CENCON.2015.7409548

[12] He, K., Liu, Y., He, Y., Chen, J., Han, X. (2019). Composition and properties of high hardness galvanized nano-waterborne paint. Nanoscience and Nanotechnology Letters, 11(1): 131-135. https://doi.org/10.1166/nnl.2019.2855

[13] Nosrati, R., Olad, A. (2015). The effect of TiO2/aluminosilicate nanocomposite additives on the mechanical and thermal properties of polyacrylic coatings. Applied Surface Science, 357: 376-384. http://dx.doi.org/10.1016/j.apsusc.2015.09.019

[14] Zaini, F.K.M., Balakrishnan, V., Syafiq, A., Rahim, N.A., Pandey, A.K., Kasi, R., Subramaniam, R. (2020). Synthesis of nano- $\mathrm{TiO}_{2}$ coating systems for solar cell. Pigment \& Resin Technology, 49(1): 26-32. https://doi.org/10.1108/PRT-02-2019-0010

[15] Nosrati, R., Olad, A., Maryami, F. (2018). Visible-light induced anti-bacterial and self-cleaning waterborne polyacrylic coating modified with $\mathrm{TiO}_{2}$ /polypyrrole nanocomposite; preparation and characterization. Journal of Molecular Structure, 1163: 174-184. https://doi.org/10.1016/j.molstruc.2018.02.097

[16] Nosrati, R., Kiani, G., Ghavidel, A.K., Rashidi, A. (2020). Improving environmental protection of waterborne polyurethane coating by adding $\mathrm{TiO}$ 2/polyaniline/HNT/CNT nanocomposite. Environmental Science and Pollution Research, 27(6): 6438-6448. https://doi.org/10.1007/s11356-019-07333-x

[17] Kumar, G.V., Chandramani, R. (2009). Investigations on $\mathrm{Fe} 3+$ doped polyvinyl alcohol films with and without gamma $(\gamma)$-irradiation. Applied Surface Science, 255(15): 7047-7050. http://dx.doi.org/10.1016/j.apsusc.2009.03.038

[18] Shekar, B.C., Veeravazhuthi, V., Sakthivel, S., Mangalaraj, D., Narayandass, S.K. (1999). Growth, structure, dielectric and AC conduction properties of solution grown PVA films. Thin Solid Films, 348(1-2): 122-129. https://doi.org/10.1016/S0040-6090(99)000279

[19] Abd El-Kader, F.H., Hamza, S.S., Attia, G. (1993). Electrical and optical studies on $\gamma$-irradiated pure and chromium-chloride-doped polyvinyl alcohol. Journal of Materials Science, 28(24): 6719-6723. https://doi.org/10.1007/BF00356421

[20] Susilawati, S., Prayogi, S., Arif, M.F., Ismail, N.M., Bilad, M.R., Asy'ari, M. (2021). Optical properties and conductivity of PVA-H3PO4 (polyvinyl alcoholphosphoric acid) film blend irradiated by $\gamma$-rays. Polymers, 13(7):

1065. 
https://doi.org/10.3390/polym13071065

[21] Sugumaran, S., Bellan, C.S. (2014). Transparent nano composite $\mathrm{PVA}-\mathrm{TiO}_{2}$ and $\mathrm{PMMA}-\mathrm{TiO}_{2}$ thin films: Optical and dielectric properties. Optik, 125(18): 51285133. http://dx.doi.org/10.1016/j.ijleo.2014.04.077

[22] Stribeck, N., Smarsly, B. (Eds.). (2005). Scattering Methods and the Properties of Polymer Materials (Vol. 130). Springer Science \& Business Media. http://dx.doi.org/10.1007/b96538

[23] Lee, J., Hong, J., Park, D.W., Shim, S.E. (2010). Microencapsulation and characterization of poly (vinyl alcohol)-coated titanium dioxide particles for electrophoretic display. Optical Materials, 32(4): 530534.

[24] Chen, C., Li, H., Jin, J., Chen, X., Cheng, Y., Zheng, Y., Liu, D., Xu, L., Song, H.W., Dai, Q. (2017). Long-lasting nanophosphors applied to UV-resistant and energy storage perovskite solar cells. Advanced Energy Materials, $\quad 7(20)$ : 1700758. https://doi.org/10.1002/aenm.201700758

[25] Zhang, H., Zou, Y., Sun, Y., Sun, L., Xu, F., Zhang, J., Zhou, H. (2015). A novel thermal-insulating film incorporating microencapsulated phase-change materials for temperature regulation and nano- $\mathrm{TiO}_{2}$ for UVblocking. Solar Energy Materials and Solar Cells, 137: 210-218. http://dx.doi.org/10.1016/j.solmat.2015.02.018

[26] Roose, B., Gödel, K.C., Pathak, S., Sadhanala, A., Baena, J.P.C., Wilts, B.D., Snaith, H.J., Wiesner, U., Grätzel, M., Steiner, U., Abate, A. (2016). Enhanced efficiency and stability of perovskite solar cells through Nd-doping of mesostructured $\mathrm{TiO}_{2}$. Advanced Energy Materials, 6(2): 1501868. https://doi.org/10.1002/aenm.201501868 